\title{
Serine/Threonine-Protein Kinase WNK1
}

National Cancer Institute

\section{Source}

National Cancer Institute. Serine/Threonine-Protein Kinase WNK1. NCI Thesaurus. Code C105604.

Serine/threonine-protein kinase WNK1 (2382 aa, $251 \mathrm{kDa}$ ) is encoded by the human WNK1 gene. This protein plays a role in controling sodium and chloride ion transport. 